\title{
Effect of gabapentin on primary surgical treatment of experimental sciatic nerve injury in rats
}

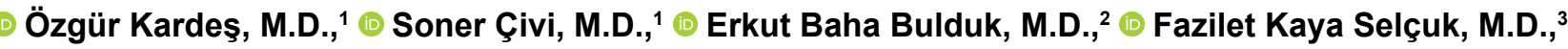

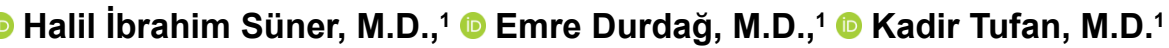

\begin{abstract}
1'Department of Neurosurgery, Başkent University Faculty of Medicine Adana Turgut Noyan Application and Research Center, Adana-Turkey 2Department of Neurosurgery, Eskişehir Government Hospital, Eskişehir-Turkey

${ }^{3}$ Department of Pathology, Başkent University Faculty of Medicine Adana Turgut Noyan Application and Research Center, Adana-Turkey
\end{abstract}

\begin{abstract}
BACKGROUND: The aim of our study is to minimize the morbidity related to nerve injury by determining the protective effects of gabapentin in experimental sciatic nerve injury and end-to-end anastomosis model in rats and to guide clinical studies on this subject.

METHODS: In our study, 40 adult male Sprague-Dawley rats were randomly divided into the following five groups: I: Only surgical intervention was applied; II: The sciatic nerve was cut properly and was repaired by end-to-end anastomosis. No additional procedure was performed; III: A single dose of gabapentin at $30 \mathrm{mg} / \mathrm{kg}$ was given after anastomosis; IV: $30 \mathrm{mg} / \mathrm{kg}$ gabapentin was given for 3 days after anastomosis; and V: $30 \mathrm{mg} / \mathrm{kg}$ gabapentin was given for 7 days after anastomosis. The experiment was terminated with high-dose thiopental $(50 \mathrm{mg} / \mathrm{kg}) 60$ days after the surgical intervention. The right sciatic nerve was taken from all animals. The obtained sections were examined immunohistopathologically.
\end{abstract}

RESULTS: Immunohistochemical properties and Schwann cell proliferation were found to be statistically significantly lower in the control group than in the other groups. Schwann cell proliferation was higher in Group 3 than in Group 5. Immunohistochemical changes were significantly lower in Group 4 than in Group 3. Axonal degeneration was also higher in Group 4 than in Group 3.

CONCLUSION: Gabapentin promotes neurological recovery histopathologically in peripheral nerve injury due to its neuroprotective properties. Our study results show that gabapentin can be used as an adjunctive therapy to primary surgical treatment after peripheral nerve injury.

Keywords: Anastomosis; gabapentin; peripheral nerve; sciatic nerve; trauma.

\section{INTRODUCTION}

The statement "Once nerves are cut, they cannot be repaired" was accepted by many surgeons until the $20^{\text {th }}$ century. ${ }^{[1]}$ First, in the $9^{\text {th }}$ and $10^{\text {th }}$ centuries, Arab surgeons began to suture peripheral nerve cuts. ${ }^{[2]}$ When we look at the nerve graft techniques, we see that the first description was given by Gabriele Ferrara in the $17^{\text {th }}$ century and that the stitches had been thrown with a tendon that was laid with red wine. ${ }^{[1]}$

Peripheral nerve injuries can occur due to mechanical, chemical, and thermal reasons. Trauma is the most common rea- son. Nowadays, it is known that peripheral nerve injury occurs in $2.8 \%$ of trauma patients. ${ }^{[3]}$

The aim of surgical treatment in peripheral nerve injuries is to ensure that the axons remain proximal to a transection so that they can reach their original distal ends during regeneration and innervate the end organs. ${ }^{[4]}$

Currently accepted treatments in peripheral nerve injuries are as follows: I) early end-to-end nerve repair for nerve transection injury and 2) graft repair when there are large gaps or tensions between damaged nerve endings. ${ }^{[5]}$ In pe-

Cite this article as: Kardeş Ö, Çivi S, Bulduk EB, Kaya Selçuk F, Süner Hİ, Durdağ E, et al. Effect of gabapentin on primary surgical treatment of experimental sciatic nerve injury in rats. Ulus Travma Acil Cerrahi Derg 2018;24:481-487.

Address for correspondence: Erkut Baha Bulduk, M.D.

Adres bilgisi: Eskişehir Devlet Hastanesi, Beyin ve Sinir Cerrahisi Kliniği, Eskişehir, Turkey

Tel: +90 222 - 2374800 E-mail: erkutbahabulduk@hotmail.com

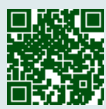

Ulus Travma Acil Cerrahi Derg 2018;24(5):48I-487 DOI: 10.5505/tjtes.2018.667I2 Submitted: 14.05.2018 Accepted: 12.09.2018 Online: 10.10.2018

Copyright 2018 Turkish Association of Trauma and Emergency Surgery 
ripheral nerve repair, tension on the neural tissues is an undesired situation. Studies on this subject show that an average of more than $10 \%$ tension applied to nerve endings to close the defect causes up to a $50 \%$ reduction in blood flow. ${ }^{[6]}$ The failure of peripheral nerve repair leads to motor and sensory deficits and painful neuropathies in the target muscle. The gold standard treatment for peripheral nerve injury is primary end-to-end repair of two transected peripheral nerve endings; if this cannot be performed, nerve endings are connected to each other using autologous sensory nerve graft. ${ }^{[7]}$

Peripheral nerve injuries were classified into three major groups according to clinical condition and microscopic changes after nerve injury by Seddon in 1943: neurapraxia, axonotmesis, and neurotmesis. Then, Sunderland expanded this classification from three to five degrees of peripheral nerve injury according to the severity of nerve injury (Table I). ${ }^{[8-10]}$

These simple classifications are still currently used, especially for the follow-up and treatment of acute nerve injuries. ${ }^{[I]}$

Gabapentin, which has entered into clinical use as an adjuvant anticonvulsant drug in the treatment of partial seizures in 1993, is widely used for neuropathic pain, migraine, and spasticity today. ${ }^{[2-14]}$ The antinociceptive, anticonvulsant, anxiolytic, and neuroprotective effects of gabapentin have been shown in various animal models. ${ }^{[15]}$

It has been suggested that the neuroprotective effects of gabapentin may be related to changes in glutamate synthesis and metabolism. ${ }^{[13,16]}$

There are many studies investigating its neuroprotective effects in cerebral ischemia, cerebral trauma, spinal cord trauma, and peripheral nerve injury.

In the literature, to the best of our knowledge, there is no any study on the efficacy of gabapentin in peripheral nerve anastomosis.

The aim of this study was to examine the effects of gabapentin on nerve healing after an experimental rat sciatic nerve transection was surgically repaired.

\section{MATERIALS AND METHODS}

The experimental protocol of our study was examined and approved by the Ethical Committee of Baskent University Medical and Health Sciences (Decision Date: 18/09/2015; Decision No: DA 15/40). Our study was supported by the Baskent University Research Fund.

The animals used in the study were obtained from the Baskent University Experimental Animal Breeding Laboratory. All the experimental steps of the study were performed in the Baskent University Experimental Animal Research Laboratory. Immunohistochemical examinations were completed in the Department of Pathology at Baskent University.

\section{Animals}

Forty male Sprague-Dawley rats (250-300 g; 12 weeks of age) were used in our study. The rats were kept at room temperature in a 12-hour light/I2-hour dark cycle in the laboratory environment for 60 days. All rats had free access to food and water. On the $60^{\text {th }}$ day of the study, the animals were sacrificed to obtain samples for immunohistochemical examinations.

\section{Groups and Surgical Procedures}

In our study, rats were randomly assigned into five groups. All rats were administered xylazine $10 \mathrm{mg} / \mathrm{kg}$ (Rompun, Bayer) and ketamine $60 \mathrm{mg} / \mathrm{kg}$ (Ketalar, Pfizer) for anesthesia intraperitoneally before surgery.

All surgical procedures were performed by a single surgeon. Surgical procedures were applied to the right sciatic nerve of the rats.

Subsequently, subjects were fixed at the prone position, four extremities and their teeth on the wooden operation table with the band.

Group I (Control) ( $\mathbf{n = 8})$ : After the administration of anesthesia, the right hind limbs were prepared for surgery using a sterile technique. Skin incision was followed by dissection of the gluteal muscles to expose the sciatic nerve, including the tibial, peroneal, and sural branches, under a surgical micro-

Table I. Seddon and Sunderland classification of peripheral nerve injury

\begin{tabular}{lll}
\hline Seddon's classification & Sunderland's classification & Injured tissues \\
\hline Neurapraxia & Grade I & Myelin \\
Axonotmesis & Gradell & Myelin, axon \\
Neurotmesis & Grade III & Myelin, axon, endoneurium \\
& Grade IV & Myelin, axon, endoneurium, perineurium \\
& Grade V & Myelin, axon, endoneurium, perineurium epineurium \\
\hline
\end{tabular}

Source 8-10. 


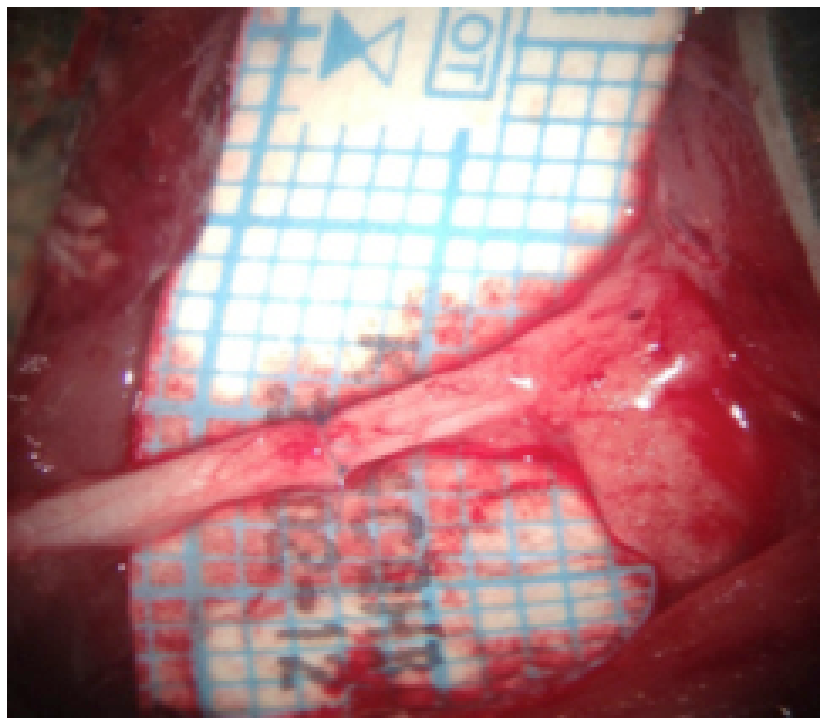

Figure 1. Image of sciatic nerve that was end to end anastomosed.

scope (Opmi 9-FC, Carl Zeiss AG, Germany). This group's sciatic nerves were only dissected under general anesthesia. No incision or anastomosis of the sciatic nerve was conducted.

Group II ( $\mathbf{n = 8 ) : ~ I n ~ a d d i t i o n ~ t o ~ t h e ~ s u r g i c a l ~ p r o c e d u r e s ~ d e - ~}$ scribed in Group I, end to end (ETE) anastomosis of the proximal and distal stumps was performed after sectioning the sciatic nerve. Anastomoses were performed using 10-0 nylon sutures. No additional treatment was applied to this group of animals (Fig. I).

Group III ( $\mathbf{n = 8 ) : ~ I n ~ a d d i t i o n ~ t o ~ t h e ~ s u r g i c a l ~ p r o c e d u r e s ~ d e - ~}$ scribed in Group II, $30 \mathrm{mg} / \mathrm{kg}$ gabapentin was administered intraperitoneally to the animals in a single dose $(4 \mathrm{~h}$ posttreatment).

Group IV ( $\mathbf{n = 8 ) : ~ I n ~ a d d i t i o n ~ t o ~ t h e ~ s u r g i c a l ~ p r o c e d u r e s ~}$ described in Group II, the animals were applied $30 \mathrm{mg} / \mathrm{kg}$ gabapentin intraperitoneally for 3 days.

Group V ( $\mathbf{n = 8 ) : ~ I n ~ a d d i t i o n ~ t o ~ t h e ~ s u r g i c a l ~ p r o c e d u r e s ~}$ described in Group II, the animals were applied $30 \mathrm{mg} / \mathrm{kg}$ gabapentin intraperitoneally for 7 days.

\section{Immunohistochemical Evaluation}

Sciatic nerves dissected from the rats were fixed in $10 \%$ buffered formaldehyde. After a routine tissue process, the samples were embedded in paraffin blocks, and 5-mm-thick sections were cut axially using a microtome (RM 2245, Leica) for hematoxylin and eosin (H\&E) staining. Slides were evaluated under a light microscope (DMI 4000 B Leica) by a pathologist who was blinded to the groups. The presence of the Schwainan cells, inflammation, and axonal degeneration were evaluated and scored semiquantitatively $(0$, absent; I, mild; 2, moderate; 3, severe/marked). Four micron-thick sections taken from the paraffin blocks were immunohistochemically stained with anti-CACNA2DI antibody (Abcam cat:2864) as the primary antibody and with rabbit Antimouse IgG (Abcam) as the secondary antibody. The results were scored semiquantitatively ( 0 , absent, I, mild; 2 , moderate; 3 , strong).

\section{Statistical Methods}

The IBM SPSS 24.0 statistic software (IBM Corporation Armonk, NY, USA) was used to analyze the variables. The Kruskal-Wallis $\mathrm{H}$ test was used to compare more than two groups with each other according to quantitative data. The Dunn's test was used for post-hoc analysis.

Quantitative variables were shown as median and range (maximum-minimum) in tables. These variables were examined at a $95 \%$ confidence level. A p-value of less than 0.05 was considered statistically significant.

\section{RESULTS}

When Schwann cell proliferation was evaluated according to the groups, there was a statistically significant difference $(\mathrm{p}<0.00 \mathrm{I})$. The median value of Schwann cell proliferation was lower in Group I (0 [0/0]) than in Groups 2, 3, 4, and 5 (respectively, I.08 [0/2]; 1.56 [1/2]; $1.07[0 / 2]$; and 0.86 [0/2]). This difference was statistically significant (all p-values $<0.001)$. Moreover, the median value of Schwann cell proliferation was higher in Group 3 (1.56 [1/2]) than in Group $5(0.86[0 / 2])$. This difference was statistically significant $(p=0.008)$. There were no significant differences between other groups $(p>0.05)$.

When axonal degeneration was evaluated according to the groups, there was a statistically significant difference $(p<0.001)$. The median value of axonal degeneration was higher in Group 4 (1.75 [1/2]) than in Group 3 (1.07 [0/2]). The median value of axonal degeneration was lower in Group $5(1.07$ [0/2]) than in Group 4 (1.75 [1/2]). These differences were statistically significant $(\mathrm{p}<0.00 \mathrm{I})$.

The median value of inflammation was found to be the same in Group I (control group) $(0.13[0 / 1])$ and in Groups 4 and 5 (respectively, $0.13[0 / 1]$ and $0.13[0 / I])$. There was no statistically significant difference between these groups $(p>0.05)$.

When we evaluated immunohistochemical changes, there was a statistically significant difference between Group I and Groups 2, 3, 4, and 5 ( $p<0.001)$. Immunohistochemical changes were significantly lower in the control group than in other groups. Moreover, the median value of immunohistochemical changes was lower in Group 4 (I [0/2]) than in Group 3 (I.64 [I/3]). This difference was statistically significant $(p<0.00 \mathrm{I})$. Immunohistochemical changes were significantly lower in Group 4 than in Group 3 (Table 2). 
Table 2. Statistical comparison of Schwann cell proliferation, axonal degeneration, inflammation, and immunohistochemical changes according to the groups

\begin{tabular}{|c|c|c|c|c|c|}
\hline & & \multirow{2}{*}{$\frac{\text { Schwann C.Proliferation }}{\text { Med. (Min./Max.) }}$} & \multirow{2}{*}{$\frac{\text { Axonal Degeneration }}{\text { Med. (Min./Max.) }}$} & \multirow{2}{*}{$\frac{\text { Inflammation }}{\text { Med. (Min./Max.) }}$} & \multirow{2}{*}{$\frac{\text { Immunohistochemistry }}{\text { Med. (Min./Max.) }}$} \\
\hline & & & & & \\
\hline Group I & $=1$ & $0(0 / 0)$ & $\mathrm{I}(\mathrm{I} / \mathrm{I})$ & $0.13(0 / 1)$ & $0.06(0 / 1)$ \\
\hline Group II & $=I I$ & $1.08(0 / 2)$ & $1.44(1 / 2)$ & $0.92(0 / 2)$ & $1.57(0 / 3)$ \\
\hline Group III & $=I I I$ & $1.56(1 / 2)$ & $1.07(0 / 2)$ & $0.53(0 / 2)$ & $1.64(1 / 3)$ \\
\hline Group IV & $=\mathrm{IV}$ & $1.07(0 / 2)$ & $1.75(1 / 2)$ & $0.13(0 / 1)$ & I $(0 / 2)$ \\
\hline Group V & $=\mathrm{V}$ & $0.86(0 / 2)$ & $1.07(0 / 2)$ & $0.13(0 / 1)$ & $1.38(0 / 3)$ \\
\hline Total & & $0.89(0 / 2)$ & $1.27(0 / 2)$ & $0.34(0 / 2)$ & $1.13(0 / 3)$ \\
\hline P-value & & $<0.001$ & $<0.001$ & $<0.001$ & $<0.001$ \\
\hline \multirow[t]{10}{*}{ Binary comparisons } & $\mathrm{I} \rightarrow \mathrm{I}$ & $<0.001$ & 0.010 & $<0.001$ & $<0.001$ \\
\hline & $\mathrm{I} \rightarrow \mathrm{III}$ & $<0.001$ & $0.64 I$ & 0.025 & $<0.001$ \\
\hline & $\mathrm{I} \rightarrow \mathrm{IV}$ & $<0.001$ & $<0.001$ & 1 & 0.001 \\
\hline & $\mathrm{I} \rightarrow \mathrm{V}$ & $<0.001$ & 0.625 & 1 & $<0.001$ \\
\hline & $\mathrm{II} \rightarrow \mathrm{III}$ & 0.053 & 0.036 & 0.098 & 0.746 \\
\hline & $\mathrm{II} \rightarrow \mathrm{IV}$ & 0.954 & 0.067 & $<0.001$ & 0.056 \\
\hline & $\mathrm{II} \rightarrow \mathrm{V}$ & 0.470 & 0.042 & $<0.001$ & 0.566 \\
\hline & $\mathrm{III} \rightarrow \mathrm{IV}$ & 0.060 & $<0.001$ & 0.025 & 0.026 \\
\hline & $\mathrm{III} \rightarrow \mathrm{V}$ & 0.008 & 0.976 & 0.025 & 0.369 \\
\hline & $\mathrm{IV} \rightarrow \mathrm{V}$ & 0.435 & $<0.001$ & 1 & 0.182 \\
\hline
\end{tabular}

Kruskal-Wallis H Test (Monte Carlo); Post Hoc Test; Dunn's Test; Med.: Medyan; Min.: Minumum; Max.: Maximum.

\section{DISCUSSION}

Peripheral nerves can be damaged due to many reasons. These include mechanical factors such as pressure, tension, and violence, as well as thermal, ischemic, radial, electrical, and chemical factors. ${ }^{[8]}$

Peripheral nerve injury, which is currently a major health problem, causes a high rate of disablement and an enormous economic burden. ${ }^{[17]}$

It constitutes an important group of diseases, especially in industrialized countries. ${ }^{[18]}$ More than 350,000 people per year in the United States are exposed to upper extremity injury. ${ }^{[18]}$

Peripheral nerve injury is seen in $2.8 \%-5 \%$ of trauma cases. ${ }^{[18,19]}$

Partial or total motor and sensory loss, loss of autonomic function, and neuropathic pain may develop due to peripheral nerve injury. ${ }^{[20]}$ This can lead to long-term disability and reduce the quality of life and cause material damage. ${ }^{[21]}$

Today, the gold standard treatment for peripheral nerve injury is ETE anastomosis. To provide a tension free primary nerve repair, different techniques can be used, such as re-routing of nerve, mobilization of nerve ends, and bone shortening. This is followed by nerve graft and nerve bridge. ${ }^{[20,22]}$
Therefore, there is a need for developing clinically relevant models to understand the peripheral nerve injury pathophysiology and to evaluate potential treatments. ${ }^{[21]}$

When we examined the literature, various techniques have been proposed to improve the functional outcomes of surgical repair of nerve transection. Nerve and vascular grafts, denatured muscle fibers, and fascial layers are examples of natural tubulization. ${ }^{[23-26]}$ Polyglycolic acid, polyglycan, polyethylene, and silicone were used for synthetic tubulization. [23,27,28] Yapici et al. ${ }^{[22]}$ reported that vascularized nerve conduit graft showed better regeneration compared to non-vascularized nerve conduit graft but that it cannot be an alternative to autogenous nerve graft.

Dos Reis et al. ${ }^{[29]}$ reported that laser therapy had positive effects on post-anastomotic regeneration of damaged nerves. Ozbek et al. ${ }^{[30]}$ showed that the use of anastomosis and genistein contributed to nerve healing in experimental sciatic nerve injury.

We also aimed to examine the effects of gabapentin on nerve healing after experimental rat sciatic nerve transection was surgically repaired.

The mechanism of action of gabapentin, which is a lipophilic 
GABA analog (an inhibitory neurotransmitter), is still unclear. It is thought that it decreases glutamate-induced cell death in both the central and peripheral nervous system by reducing neuronal cytoplasmic glutamate concentrations in vivo through selective antagonism of an AMPA-type glutamate receptor. ${ }^{[12,15,3 \mid]}$ There are many studies showing the neuroprotective effects of gabapentin. Kale et al. ${ }^{[15]}$ reported that gabapentin had a neuroprotective effect in spinal cord ischemia-reperfusion injury in rabbits. Rekling et al. ${ }^{[32]}$ showed that gabapentin had a neuroprotective effect on rat hippocampus.

In our study, Schwann cell proliferation, axonal degeneration, and inflammation were not observed in the control group (Fig. 2). The nerve tissue with prominent Schwann cell proliferation was in Group 3, and the nerve tissue with prominent inflammation in addition to Schwann cell proliferation was in Group 2 (Fig. 2).

There was no statistically significant difference between Group I and Groups 4 and 5 in terms of inflammation. This result proved the strong anti-inflammatory activity of gabapentin. Although not statistically significant, even in the single-dose gabapentin group (Group 3), inflammation was less in Group 2. After 3 and 7 days, it was proven that in- flammation was at the level of the control group. And these findings were meaningful with the literature. ${ }^{[14,16,30,33,34]}$

In Group 4, significant axonal degeneration was observed (Fig. 2).

In our study, there was a statistically significant difference between the control group (Group I) and other groups in terms of Schwann cell proliferation. Schwann cell proliferation was significantly lower in the control group. When the relationships between the other groups were evaluated, Schwann cell proliferation was lower in Group 5 than in Group 3.

In an experimental setting, behavior is accepted as motor symptoms of physiopathological processes. Behavioral improvement after peripheral nerve injury is the most important measure of healing for real patients. ${ }^{[18]}$ Functional evaluation is a standard metric for motor function assessment that reflects nerve function after peripheral nerve injury. ${ }^{[30]} \mathrm{How}$ ever, functional evaluation was not performed in our study because nerve regeneration and functional recovery were not completed on the $60^{\text {th }}$ day. This can be investigated by a longterm study; however, it is not possible to evaluate this with the results of this study. ${ }^{[3]}$
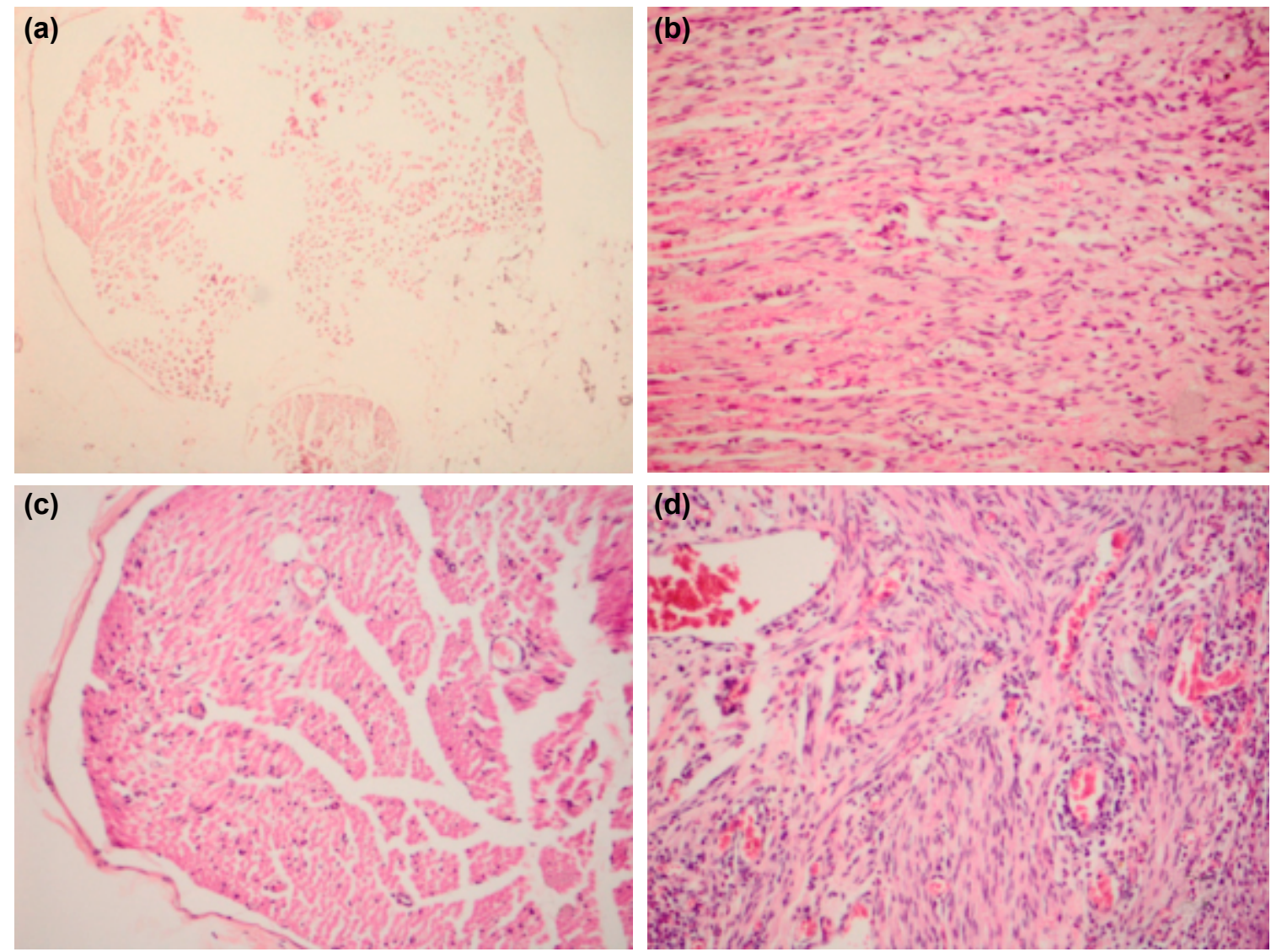

Figure 2. (a) Control group; Schwann cell proliferation, axonal degeneration, and no inflammation (Group 1) (x10, H\&E). (b) Neuronal tissue with prominent Schwann cell proliferation (Group 3) (x20, H\&E). (c) Neural tissue showing significant axonal degeneration (Group 4) (x20, H\&E). (d) Significant Schwann cell proliferation and inflammation (Group 2) (x20, H\&E). 
We must travel a considerable distance to achieve the ideal treatment of peripheral nerve injury. The processes of degeneration and regeneration after nerve injury are not fully understood with current information. The clarification of these processes will constitute the basis for progress in the treatment of peripheral nerve injury. ${ }^{[3]}$

\section{Conclusion}

The results of our study show that gabapentin can be used as an adjuvant therapy to surgical treatment after peripheral nerve injury. Gabapentin functionally and histopathologically promotes neurological recovery in peripheral nerve injury.

\section{However, the importance of microsurgery experience in treatment should not be forgotten.}

\section{Conflict of interest: None declared.}

\section{REFERENCES}

1. Benli K. Periferik Sinir Cerrahisinin Onemi. Türk Nörosiriirji Dergisi 2005;15:196-7.

2. Akbay A. Periferik Sinirin Mikroanatomisi ve Sinir Kesilerinde Uygulanan Cerrahi Teknikler. Türk Nörosirürji Dergisi 2005;15:198-201.

3. Özer, H. Deneysel Siyatik Sinir Yaralanmasında Poli (3-Hidroksibütirat)(Phb) Vechitosan Kaplı Tübüler Greftler ile Birlikte Mezenșimal Kök Hücre Kullanımının Aksonal rejenerasyona Etkisi. Ankara: Hacettepe Üniversitesi; 2013.

4. Horn KL, Crumley RL. The physiology of nerve injury and repair. Otolaryngol Clin North Am 1984;17:321-33.

5. Brandt KE, Mackinnon S. Microsurgical repair of peripheral nerves and grafts. In: Aston SJ, Beasley RW, Thorne CH, editors. Grabb and Smith's Plastic Surgery. 5th. New York: Lippincott Williams \& Wilkins; 1997.p. 79-90.

6. Trumble TE, McCallister WV. Repair of peripheral nerve defects in the upper extremity. Hand Clin 2000;16:37-52.

7. Battiston B, Tos P, Conforti LG, Geuna S. Alternative techniques for peripheral nerve repair: conduits and end-to-side neurorrhaphy. Acta Neurochir Suppl 2007;100:43-50.

8. Yüksel TN. Deneysel olarak ratlarda oluşturulan periferik sinir yaralanmalarında telmisartanın rolünün araştırılması. Erzurum: Atatürk Üniversitesi Sağlık Bilimleri Enstitüsü; 2013.

9. Seddon H. Three types of nerve injury. Brain 1943;66:237-88.

10. Sunderland $S$. A classification of peripheral nerve injuries producing loss of function. Brain 1951;74:491-516.

11. Grant, GA Kliot M. In: Winn HR, editor. Youmans neurological surgery. 5th. Saunders; 2004.

12. İstan GK, Erbayraktar Z, Gökmen N, Bağrıyanık A, Kıray M, Erbayrak$\operatorname{tar}$ SR. Evaluation of Neuroprotective Efficacy of Gabapentin in Experimental Spinal Cord Injury. Sinir Sist Cerrahisi Derg 2015;4:169-84.

13. Kim YK, Leem JG, Sim JY, Jeong SM, Joung KW. The effects of gabapentin pretreatment on brain injury induced by focal cerebral ischemia/reperfusion in the rat. Korean J Anesthesiol 2010;58:184-90.

14. Dougherty JA, Rhoney DH. Gabapentin: a unique anti-epileptic agent. Neurol Res 2001;23:821-9.

15. Kale A, Börcek AÖ, Emmez H, Yildirim Z, Durdağ E, Lortlar N, et al. Neuroprotective effects of gabapentin on spinal cord ischemia-reperfusion injury in rabbits. J Neurosurg Spine 2011;15:228-37.
16. Taylor CP, Gee NS, Su TZ, Kocsis JD, Welty DF, Brown JP, et al. A summary of mechanistic hypotheses of gabapentin pharmacology. Epilepsy Res 1998;29:233-49.

17. Sezer A, Guclu B, Kazanci B, Cakir M, Coban MK. Neuroprotective effects of agmatine in experimental peripheral nerve injury in rats: a prospective randomized and placebo-controlled trial. Turk Neurosurg 2014;24:196-201.

18. Kemp SWP, Cederna PS, Midha R. Comparative outcome measures in peripheral regeneration studies. Exp Neurol 2017;287:348-57.

19. Noble J, Munro CA, Prasad VS, Midha R. Analysis of upper and lower extremity peripheral nerve injuries in a population of patients with multiple injuries. J Trauma 1998;45:116-22.

20. Li R, Wu J, Lin Z, Nangle MR, Li Y, Cai P, et al. Single injection of a novel nerve growth factor coacervate improves structural and functional regeneration after sciatic nerve injury in adult rats. Exp Neurol 2017;288:1-10.

21. Ganguly A, McEwen C, Troy EL, Colburn RW, Caggiano AO, Schallert $\mathrm{TJ}$, et al. Recovery of sensorimotor function following sciatic nerve injury across multiple rat strains. J Neurosci Methods 2017;275:25-32.

22. Yapici AK, Bayram Y, Akgun H, Gumus R, Zor F. The effect of in vivo created vascularized neurotube on peripheric nerve regeneration. Injury 2017;48:1486-91.

23. Cemil B, Ture D, Cevirgen B, Kaymaz F, Kaymaz M. Comparison of collagen biomatrix and omentum effectiveness on peripheral nerve regeneration. Neurosurg Rev 2009;32:355-62.

24. Chiu DT, Janecka I, Krizek TJ, Wolff M, Lovelace RE. Autogenous vein graft as a conduit for nerve regeneration. Surgery 1982;91:226-33.

25. Cruz NI, Debs N, Fiol RE. Evaluation of fibrin glue in rat sciatic nerve repairs. Plast Reconstr Surg 1986;78:369-73.

26. Lundborg G, Hansson HA. Nerve regeneration through preformed pseudosynovial tubes. A preliminary report of a new experimental model for studying the regeneration and reorganization capacity of peripheral nerve tissue. J Hand Surg Am 1980;5:35-8.

27. Meek MF, Dijkstra JR, Den Dunnen WF, Ijkema-Paassen J, Schakenraad JM, Gramsbergen A, et al. Functional assessment of sciatic nerve reconstruction: biodegradable poly (DLLA-epsilon-CL) nerve guides versus autologous nerve grafts. Microsurgery 1999;19:381-8.

28. Valero-Cabré A, Tsironis K, Skouras E, Perego G, Navarro X, Neiss WF. Superior muscle reinnervation after autologous nerve graft or poly-Llactide-epsilon-caprolactone (PLC) tube implantation in comparison to silicone tube repair. J Neurosci Res 2001;63:214-23.

29. dos Reis FA, Belchior AC, de Carvalho Pde T, da Silva BA, Pereira DM, Silva IS, et al. Effect of laser therapy $(660 \mathrm{~nm})$ on recovery of the sciatic nerve in rats after injury through neurotmesis followed by epineural anastomosis. Lasers Med Sci 2009;24:741-7.

30. Ozbek Z, Aydin HE, Kocman AE, Ozkara E, Sahin E, Bektur E, et al. Neuroprotective Effect of Genistein in Peripheral Nerve Injury. Turk Neurosurg 2017;27:816-822.

31. Petroff O, Manor D, Behar K. Gabapentin decreases cortical glutamate rapidly in a rat model. Epilepsy Res 1997.

32. Rekling JC. Neuroprotective effects of anticonvulsants in rat hippocampal slice cultures exposed to oxygen/glucose deprivation. Neurosci Lett 2003;335:167-70.

33. Emmez H, Yildirim Z, Kale A, Tönge M, Durdağ E, Börcek AO, et al. Anti-apoptotic and neuroprotective effects of $\alpha$-lipoic acid on spinal cord ischemia-reperfusion injury in rabbits. Acta Neurochir (Wien) 2010;152:1591-600.

34. Emmez H, Börcek AÖ, Kaymaz M, Kaymaz F, Durdağ E, Civi S, et al. Neuroprotective effects of gabapentin in experimental spinal cord injury. World Neurosurg 2010;73:729-34. 
DENEYSEL ÇALIŞMA - ÖZET

\section{Sıçanlarda deneysel olarak oluşturulan siyatik sinir hasarında gabapentinin primer cerrahi tedaviye etkisi \\ Dr. Özgür Kardeş, ${ }^{1}$ Dr. Soner Çivi, ${ }^{1}$ Dr. Erkut Baha Bulduk, ${ }^{2}$ Dr. Fazilet Kaya Selçuk, ${ }^{3}$ Dr. Halil İbrahim Süner, ${ }^{1}$ Dr. Emre Durdağ, ${ }^{1}$ Dr. Kadir Tufan ${ }^{1}$}

${ }^{1}$ Başkent Üniversitesi Tıp Fakültesi, Adana Dr. Turgut Noyan Uygulama ve Araştırma Merkezi, Beyin ve Sinir Cerrahisi Anabilim Dalı, Adana ${ }^{2}$ Eskişehir Devlet Hastanesi, Beyin ve Sinir Cerrahisi Kliniği, Eskişehir

${ }^{3}$ Başkent Üniversitesi Tıp Fakültesi, Adana Dr. Turgut Noyan Uygulama ve Araştırma Merkezi, Patoloji Anabilim Dalı, Adana

AMAÇ: Çalışmamızın amacı; sıçanlarda deneysel olarak oluşturulan siyatik sinir yaralanması ve uç-uca anastomoz yapılması modelinde gabapentinin koruyucu etkilerini belirleyerek sinir yaralanmasına bağlı morbiditeyi en aza indirmek ve bu konudaki klinik çalısmalara yön vermektir.

GEREÇ VE YÖNTEM: Çalışmamızda 40 adet yetişkin, erkek, Sprague-Dawley cinsi sıçanlar; rastgele I: Sadece cerrahiye maruz kalan, II: siyatik sinirleri düzgün bir şekilde kesilip tekrar uç-uca anastomoz yapılan ve ek herhangi bir işlem yapılmayan, III: anastomoz yapllı tek doz $30 \mathrm{mg} / \mathrm{kg}$ gabapentin verilen, IV: anastomoz yapılıp üç gün $30 \mathrm{mg} / \mathrm{kg}$ gabapentin verilen, V: anastomoz yapılıp yedi gün $30 \mathrm{mg} / \mathrm{kg}$ gabapentin verilen olmak üzere beş gruba ayrıldı. Cerrahi işlemden 60 gün sonra yüksek doz tiyopental $(50 \mathrm{mg} / \mathrm{kg})$ ile deney sonlandıııldı. Tüm hayvanların sağ siyatik sinirleri alındı ve elde edilen kesitler immünohistopatolojik olarak incelendi.

BULGULAR: İmmünohistokimyasal özellikler ve Schwann hücre proliferasyonu kontrol grubunda, diğer gruplara kıyasla istatistiksel olarak anlamlı daha az oranda saptandı. İkili gruplar arasında ise Grup 3'de 5'e oranla daha fazla hücre proliferasyonu görüldü. Grup 4'deki immünohistokimyasal değişiklikler Grup 3'e göre anlamlı oranda az saptandı. Ayrıca axonal dejenerasyon da Grup 4'de Grup 3'e oranla daha fazla bulundu.

TARTIŞMA: Gabapentin, histopatolojik olarak periferik sinir yaralanmasında nöroprotektif özelliği ile nörolojik düzelmeyi teşvik eder. Çalışmamızın sonuçlarında, gabapentinin, periferik sinir hasarı sonrasında primer cerrahi tedaviye ek tamamlayıcı bir tedavi olarak kullanılabilirliğini göstermektedir.

Anahtar sözcükler: Anastomoz; gabapentin; periferik sinir; siyatik sinir; travma.

Ulus Travma Acil Cerrahi Derg 2018;24(5):48I-487 doi: 10.5505/tjtes.20।8.667।2 